\title{
Role Expectations and Observed Performance of School Counsellors in Edo State of Nigeria
}

\author{
*Dr (Mrs) A. I. Ojeme \\ Institute Of Education, University Of Benin,, P.M.B 1154. Benin City, Edo State, Nigeria
}

\begin{abstract}
This study investigated school counsellors' awareness of their cognate role expectations and the observed performance of these roles. Three research questions were raised as guide for the study. The descriptive survey research design was used for the study. Purposive sampling procedure was used to select twenty public schools with professional counsellors in Edo State. From the selected schools, five students each from Senior Secondary School Two (SS2), who volunteered to participate in the study, were used for data collection. Two structured selfconstructed questionnaire were personally administered by the researcher, one for counsellors and one for students. The data obtained were analysed using frequency counts and percentages, and mean ratings. The results obtained revealed that counsellors were aware of all their role expectations except in the area of appraisal service, counsellors role performances were unsatisfactory in the areas of orientation service, appraisal service, vocational and personal social services and information service. The counsellors however, performed satisfactorily in other five areas such as; individual and group counselling, educational counselling, follow up and referral counselling services and there were evidences of constraints to effective implementation of counselling services in the schools studied. Based on the findings of the study, some recommendations were made that school principals should be more supportive of the school counsellors' work and also there should be regular workshop for training and retraining of school counsellors to enable them upgrade their knowledge and skills. It is hoped that the recommendations put forward in this paper, would go a long way in promoting counselling services in the schools, while further sustained research on this subject matter is required.
\end{abstract}

Keywords: Counsellors, cognate role, expectations, observed performance.

DOI: $10.7176 / \mathrm{JEP} / 12-36-12$

Publication date: December $31^{\text {st }} 2021$

\section{Introduction}

Counselling services are among the educational services recognized by the National Policy of Education in 2013 and subsequent editions of 1998, 2004 and 2013 respectively. The counsellor as a service provider is a supportive personnel that wants to ensure that learners in the school system are properly positioned to actualize their potentials. This is a professional function of the counsellor in the school system. This supportive role cannot be ignored if Nigerian education is expected to assist learners fully actualize its development and transformational objectives of learners in Nigerian education.

The importance of the role of counsellors as referred to above is one of the reasons why every school is expected to have a minimum of one professional counsellor among the staff. However, the extents to which these roles are being performed by the school counsellors are not well known empirically. In order to ensure that the expectation of the National Policy of Education, with reference to the role of the school counsellors in the school system are achieved, it becomes an imperative for a study to be conducted to ascertain the extent to which these roles are being performed.

Also, it is well known that as professionally trained personnel, the counsellors could be said to be well aware of their expected roles in the schools, just as other support services providers. But for progress to be made, it is important that systematically and empirically focused studies are conducted to determine whether there is a one on one correspondence between role expectations and performance of school counsellors in Nigerian education. The counsellors role involves many varied and vital roles. The guidance counsellor is professionally trained to provide a programme of services to individual students based upon their needs, understanding of their immediate environment, the influences of the environmental factors on the students and the unique features of their schools.

Notable scholars in the field of counselling psychology have defined the roles of counsellors as assisting students in their educational development; making appropriate vocational choice and helping them resolve their personal social problems. According to Schmidt (2014), counsellors render services to students to enable them reach their educational goals, choose an appropriate career direction and develop as fully functioning members of the society. Aligning with the above point, Anagbogu (2002) asserted that the guidance counsellor, is a professional, who provides educational, vocational and personal social counselling to students, through diagnoses, planning, predicting, interpretation and evaluation to aid the students Personal growth and development. Aligning with the above opinion, Hammed (2019), noted that the counsellor is a professional educator with specialized training in counselling and related guidance services which proffer solution to the developmental needs and problems of all individuals. 
The effective delivery of counselling services requires the counsellor to consider the clients' interest, objectives, potentials and needs amongst others. Also Egbo (2013) in agreement with scholars in the field of counselling psychology, identified the counsellor as a life educator and human resource developer, who assist clients to actualize their excellent academic dreams, pilot vocational well-being and skillfully resolve personal social problems. Yakasai (2019), asserted that the counsellors' prescribed role is to facilitate instruction by removing students' learning impediments. This process, he further stated, includes sequential activities to be organized and discharged by certified school counsellors with the cooperation of administrators, teachers, students and parents.

The fundamental goal of counselling is to help students who manifest behavioural problems effect change in behaviour. Denga (2019), opined that the spirit of altruism embedded in guidance, makes it conspicuously a helping profession since every individual needs help at one time or the other. In the same vein, some other key writers of this subject matter such as Okeke (2003), Idowu (2004), Omebe (2005), Egbochuku (2008), “Author" (2010), kolo and Bawa (2012). Jiya (2014), Egbo (2015) and Denga (2019) have enumerated the basic guidance and counselling services expected of a school counsellor to include educational, vocational and personal-social counselling, appraisal service, information service, planning, placement and follow up services, orientation and referral services. Basically, these services are designed to assist clients to understand themselves and their world so that they may live a more productive, more rewarding and self-satisfying life. The professional school counsellors render the following comprehensive guidance programmes; he or she helps students function more effectively in their school progress. Students are faced with many educational problems which include persistent poor academic performance and anxiety over examination, problem of school adjustment, selection of subjects so as to pursue any area of study, inability to develop effective study habit and lack of motivation to learn etc.

They help students to solve many of these educational problems and help them reach their potentials in their school progress through counselling.

The professional school counsellor assists students to make the right choice of occupation through matching their personal attributes and their background with suitable jobs and employment opportunities. Students may have vocational problems which include changing from one course to the other, succumbing to pressure from their peers to study a particular course, wrong choice of subjects leading to a wrong choice of career. The counsellor assists students with their planning, preparation for, and adjustment to the world of work in order to enhance their actualization and fulfillment in life.

In personal-social guidance and counselling, the school professional counsellor deals with psychological and emotional issues that affect students. Personal-social problems include personality maladjustment such as anger, unhappiness, phobia, excessive frustration, inability to meet needs, restlessness, mood swing, disappointment from relationship, problems with teachers, problem of drug abuse or misuse by some students. These are problems that may affect students emotional, cognitive or behavioural functioning. The school counsellors through counselling assist students to proffer solutions to the problems.

The professional school counsellor uses appraisal service to collect, analyse and interpret systematic and objective data about students, which the counsellor relates to the students' parents, teachers and others, who are professionally concerned. Through appraisal service, the school counsellor can identify an exceptional student.

Another vital service renders by the school counsellor is information service. Information is an ingredient used by the school counsellor for decision making. It is the duty of a professional school counsellor to collect and disseminate relevant information to students and parents on school subjects and courses, careers and career training opportunities.

Planning, Placement and Follow Up Services are used by the school counsellor to assists the students to direct their interest, abilities and talents to areas, where they are needed for optimal productivity. The counsellor follows up or monitor the progress of students so far made in their chosen course of study and to enable further decision if need be.

Through orientation and referral services, the professional school counsellors are able to assist new students to feel emotionally secure and adjusted in a new environment especially and may refer students to see other specialists like doctors, dentists and pastors depending on the need of the students.

From the foregoing, it can be deduced that the role of a counsellor is to assist students manage their behaviour, promote students learning and plan for their future career. However, what is seemingly unclear is the extent to which professional school counsellors perform these roles. In the opinion of Torbaba (2009), the roles of school guidance counsellors need to be clarified, for a successful organization of any guidance and counselling programme. He further asserted, that the lack of clarification of counsellors' roles could lead to some unpleasant experiences by young training counsellors in the school system. Robins (2001) opined that professional counsellors, need to maintain and enhance their knowledge, expertise and competence in the discharge of their professional duties. They must be alert to the ever changing needs of the society and humans, quickly acquire and improve on the skills that could guarantee their existence. In the same vein, Kolo, Bawa and Adisa (2012), posited that professional counsellors must demonstrate practical skills that would endear them to their clients, for them to be 
seen as relevant and useful in their field. In agreement with the above opinion, Nwamuo and Ugwuegbulam (2011) admonished professional school counsellors to carry out comprehensive guidance and counselling programmes and be accountable for their work in the school system.

The foregoing suggest uncertainty as to whether counsellors are aware of their cognate roles and if these roles are effectively and efficiently carried out by the school counsellors in Edo state of Nigeria.

This study is therefore, designed to determine empirically the extent to which role expectations and performance of the cognate roles of the school counsellors are being fulfilled in schools.

\subsection{Statement of the problem}

The introduction of guidance and counselling in Nigeria dates back to 1959 (Egbochukwu, 2018). This service was first introduced by a group of Rev. Sisters with the goal of assisting students in making appropriate vocational choice. It was also aimed at assisting students in finding solutions to educational problems. However, this service seemed not to be fully realised given the educational situation today, characterized by incidents of cultism, bullying and declining students' performances in their external examinations such as West African Examination Council (WAEC), National Examination Council (NECO) and Joint Admission and Matriculation Board (JAMB), it is conceivable that school counsellors may not have been most competently effective in the performance of their cognate professional roles.

The problem of this study therefore, is predicated on the apparent insufficient empirical evidence of the extent to which school counsellors are carrying out their expected cognate roles in the school system using the comparative framework or model of the expected and role enactment by the school counsellor.

\subsection{Purpose of the study}

The purpose of this study is to ascertain if professional school counsellors are aware of their cognate professional roles and the extent to which school counsellors are performing their cognate roles by matching their role performance with role expectation.

\subsection{Research Questions}

Three research questions were addressed by this study;

1. Are school counsellors aware of their expected cognate roles or functions in the school system?

2. Do school counsellors perform their cognate roles or functions in the school system?

3. What are the constraints to counsellors role performance in secondary schools?

\subsection{Assumption}

The assumption is that if counsellors truly carryout their school professional roles as prescribed, students are likely to excel in their studies, both in internal and external exams. (Public examination e.g. West African Examination Council (WAEC), National Examination Council (NECO) and Joint Admission and Matriculation Board (JAMB), failure and school dropout rates will be minimized as well as social vices.

\section{Methodology}

The descriptive survey research design was employed in the study. The variables of the study which were not manipulated included the independent variable, which is the cognate roles of the school counsellors and the dependent variable which is the counsellors' observed performance.

Two separate and structured self-constructed research instruments designed to elicit information from counsellors and students were developed after a review of related literature in the subject-matter. The first instrument consists of sections A and B. Section A consisted of ten items which sought to elicit information from professional school counsellors on the awareness of their professional role expectation. Section B which consisted of five items, elicited information from the counsellors, on the challenges encounter in the process of discharging their core counselling duties. The second instrument, was designed to collect information from students only. The instrument consists of ten items, which elicited information on students' observed performance of school counsellor's roles.

The instruments were validated by two experts in the field of guidance and counselling and measurement and evaluation. Their contributions were used to prepare the final draft before it was finally administered to the respondents. A reliability co-efficient of 0.79 and 0.85 were obtained from the counsellors and students instruments respectively, using the test retest method of establishing reliability. The instruments were therefore accepted as reliable.

Purposive sampling procedure was used to select twenty public schools from Edo State. Only schools with professional counsellors were selected since there are schools without professional counsellors in Edo State of Nigeria. One counsellor was taken from each of the selected schools, making it a total of twenty counsellors that participated in the study. Five students each from the selected senior secondary schools, who volunteered to 
participate in the study, were used, making it a total of 100 senior secondary school students. A total of 120 copies of the structured questionnaire were personally administered by the researcher, with the help of a research assistant. Twenty of the questionnaire elicited information from the school counsellors, while the remaining 100 questionnaire elicited information from the students. In order to ensure high response rate, the researcher and the research assistant waited patiently to collect the completed questionnaire from the counsellors and students on the spot.

The responses to the questionnaire items in section A of the instrument for counsellors only, were analysed using comparison of the number of respondents who answered in either of the two dimensional alternatives of 'Aware' or 'not Aware' to the items. These responses were quantified by frequency counts and percentages. Also, in section $\mathrm{B}$, the data were analysed using frequency counts and percentages for the number of respondents who answered 'Yes' or 'No' to the items.

However, in section $\mathrm{C}$ of the instrument for students only, the responses to the items were scored in a descending order as follows; 4 points for Excellent, 3 points for Good, 2 points for Fair and 1 point for poor. To determine the cut-off point, the mean for the values assigned to the scaled item was established (2.5). Responses with the mean of 2.50 and above were regarded as satisfactory while responses with mean below 2.50 were regarded as unsatisfactory.

\section{Results of the study}

\subsection{Research question one}

Are school counsellors aware of their expected roles in the school system?

Table 1: School Counsellors awareness of their expected roles in the school system

\begin{tabular}{|c|c|c|c|c|}
\hline Questionnaire items. & Aware & $\%$ & Not aware & $\%$ \\
\hline Individual counselling of students. & 19 & 95 & 01 & 05 \\
\hline Group counselling of students. & 17 & 85 & 03 & 15 \\
\hline Planning of orientation for new students. & 15 & 75 & 05 & 25 \\
\hline Carrying out Appraisal service. & 09 & 45 & 11 & 55 \\
\hline Assisting students to make appropriate career choice. & 20 & 100 & 00 & 00 \\
\hline Assisting students to resolve educational problems. & 15 & 75 & 05 & 25 \\
\hline Helping students to resolve personal-socio problems with their parents. & 15 & 75 & 05 & 25 \\
\hline Following up on students' progress in their choice of study. & 12 & 60 & 08 & 40 \\
\hline Helping students to obtain and disseminate information. & 15 & 75 & 05 & 25 \\
\hline Referring students to other specialists. & 16 & 80 & 04 & 20 \\
\hline
\end{tabular}

Table 1 shows school counsellors' awareness of their expected roles in the school system. It further shows that $95 \%$ of the school counsellors agreed that they were aware that their role is to counsel students individually, while $0.5 \%$ were not aware. Eighty five percent of the counsellors sampled were aware of group counselling as their role while $15 \%$ were not. With respect to planning of orientation programme for new students, $75 \%$ of the school counsellors accepted that it was their role, while $25 \%$ do not. On the issue of counsellors carrying out appraisal service to students, $45 \%$ of counsellors were aware while $55 \%$ were not aware. All the counsellors sampled agreed that they were aware that their role is to assist students to make appropriate career choice. Seventy five percent agreed that assisting students to resolve educational problems is the role of the school counsellors while $25 \%$ were not aware. On the issue of helping students to resolve personal-socio problems with their parents, $75 \%$ of the school counsellors agreed it was their duty while $25 \%$ were not aware. Sixty percent of counsellors were aware that it was their duty to follow up on students' progress in their choice of study while $40 \%$ were not aware. With respect to helping students to obtain and disseminate information, $75 \%$ of the counsellors sampled agreed that they were aware while $25 \%$ of counsellors sampled were not. On the issue of referring students to other specialists $80 \%$ of counsellors claimed that they were aware while $20 \%$ were not aware.

\subsection{Research Question Two}

Do school counsellors perform their roles or functions in the school system? 
Table 2: students rating of the observed performance of professional counsellors' roles

\begin{tabular}{|l|l|l|l|l|l|l|}
\hline Questionnaire items & Excellent & Good & Fair & Poor & Mean & Decision \\
\hline $\begin{array}{l}\text { The school counsellor renders individual } \\
\text { counselling service to students }\end{array}$ & 10 & 52 & 22 & 16 & 2.56 & Satisfactory \\
\hline $\begin{array}{l}\text { The school counsellor does not render group } \\
\text { counselling service to students }\end{array}$ & 28 & 50 & 08 & 14 & 2.92 & Satisfactory \\
\hline $\begin{array}{l}\text { The school counsellor plans orientation } \\
\text { programme for new students }\end{array}$ & 02 & 30 & 55 & 13 & 2.21 & Unsatisfactory \\
\hline Students are appraised by the school counsellors & 05 & 25 & 15 & 55 & 1.08 & Unsatisfactory \\
\hline $\begin{array}{l}\text { The school counsellor assist students to make } \\
\text { appropriate vocational choice of career }\end{array}$ & 15 & 30 & 35 & 20 & 2.04 & Unsatisfactory \\
\hline $\begin{array}{l}\text { Students educational problems are resolved by the } \\
\text { school counsellor }\end{array}$ & 18 & 52 & 21 & 09 & 2.79 & Satisfactory \\
\hline $\begin{array}{l}\text { The school counsellor communicates effectively } \\
\text { with parents to resolve students personal-social } \\
\text { problems }\end{array}$ & 02 & 15 & 53 & 30 & 1.89 & Unsatisfactory \\
\hline $\begin{array}{l}\text { The school counsellors follow up students' } \\
\text { progress in their school work }\end{array}$ & 16 & 40 & 29 & 15 & 2.57 & Satisfactory \\
\hline $\begin{array}{l}\text { Career information is disseminated to students by } \\
\text { the school counsellor }\end{array}$ & 12 & 30 & 16 & 42 & 2.12 & Unsatisfactory \\
\hline Students are referred to other specialists & 25 & 38 & 27 & 10 & 2.78 & Satisfactory \\
\hline
\end{tabular}

Table 2 showed the mean ratings of the observed performance of professional school counsellors in the school system. The mean ranges from 1.08 to 2.95 . The table shows that the performance of counsellors in the school system as rated by students are unsatisfactory in the areas of ;organising orientation for new students, carrying out appraisal of students, assisting students to make appropriate vocational choice of career, assisting students to resolve their personal-social problems and collecting and disseminating career information to the students.

However, the Table shows that the performance of school counsellors were rated satisfactory in the areas of individual and group counselling services, assisting students with educational problems, follow up and referral services.

\subsection{Research Question Three}

What are the constraints to the counsellor's role performance in the school system?

Table 3: Counsellors' Responses to counselling services constraints

\begin{tabular}{|l|l|l|l|l|}
\hline Questionnaire items & Yes & $\%$ & No & $\%$ \\
\hline Does your school have a conducive counselling office? & 05 & 25 & 15 & 75 \\
\hline Does your school have counselling working materials such as; & & & & \\
(i) Counselling books $\quad$ Computers & 03 & 15 & 17 & 85 \\
(ii) $\quad 01$ & 05 & 19 & 95 \\
(iii) Bulletin boards & 07 & 35 & 13 & 65 \\
(iv) Video recording tapes & 00 & .00 & 20 & 100 \\
(v) File folders & 12 & 60 & 08 & 40 \\
\hline Are counselling programmes funded by the school authority? & 05 & 25 & 15 & 75 \\
\hline Is counselling period allocated on the school time table? & 05 & 25 & 15 & 75 \\
\hline Does your school principal assign non-counselling duties to you? & 12 & 60 & 08 & 40 \\
\hline
\end{tabular}

From Table 3 above, it is observed that $75 \%$ of respondents indicated non-availability of conducive counselling office in their school. Also various working counselling tools such as counselling books, computers, bulletin boards, video recording tapes and file folders are not adequately provided in the schools sampled as indicated by the school counsellors. The Table also shows that $75 \%$ of respondents indicated non-funding of counselling programmes in their schools and non-inclusion of counselling period on their school time table. Also, the Table revealed that $60 \%$ of counsellors are deployed to perform non-counselling duties while $40 \%$ are not.

\section{Discussion of Findings}

\subsection{Awareness of professional school counsellors of their expected roles}

The result of research question one indicated that counsellors are aware of their expected roles in schools. Awareness level varied from one role to the other. The roles where there are indications of common acceptance of awareness included assisting students to make appropriate career choice, working closely with teaching staff for the benefits of the students, individual and group counselling, assisting students to resolve educational problems, helping students to resolve personal-social problems, organizing orientation for new students, collection and 
dissemination of information to students amongst others. The finding agrees with Nwamuo and Ugwuegbulam (2011) who reported that school counsellors are aware of their comprehensive guidance and counselling services and should be accountable for their work and serve all students in the school system. In the same vein, the report of Ngwakwe (2016) is in consonance with the finding of this present study as stated in this paper.

This is obviously not surprising because school counsellors are professionally trained to provide these services to students, parents, and teachers. The curriculum for training counsellors enables them to assist the students to reach their educational goals, choose an appropriate career direction and develop as fully functioning members of a democratic society (Schmidt, 2014).

Also the result, however, showed that many counsellors disagreed that carrying out an appraisal service, is their duty. Perhaps counsellors view the appraisal service as the teachers responsibility and may feel over-burden by the performance of such service in addition to the performance of their core counselling duties. It could also be that such programme is not funded by the school authority.

\subsection{The Observed Performance of School Counsellors Roles}

The findings on research question two revealed unsatisfactory counsellors performance in the discharge of some of their legitimate duties as indicated by the students that were sampled for the study. The findings showed that counsellors performance was unsatisfactory to students in the areas of providing orientation programme for new students, carrying out appraisal services, assisting students to make an appropriate vocational choice of career by helping them with the choice of subjects combination, helping students to resolve their personal-socio problems, obtaining and disseminating career information to students.

From the areas of services enumerated above, counsellors' appraisal of students and personal social counselling were rated least unsatisfactorily with a mean of 1.08 and 1.89 respectively. The outcome of this study is not surprising since some of the professional school counsellors claimed that they were not aware these services were inclusive in their professional core duties. However, the ratings of counsellors' unsatisfactory performance in the area of vocational counselling are a pointer that professional school counsellors are not fully committed to their core counselling duties. It is common knowledge that vocational guidance counselling is one of the major focuses of school based counselling services. All school counsellors sampled indicated that they are aware of this role as their core counselling duty. It is therefore, surprising that the rating of their performance in this regard is unsatisfactory. This finding is in consonance with the opinion of Unachukwu and Igborgbor (2001) who reported that students are not properly guided and so they enter into wrong profession, which leads to job incompetence and job dissatisfaction. With the increasing rate of unemployment, the onus is on school counsellors to properly guide the students in the area of entrepreneurial education. As asserted by Tambawal and Abdulkarim (2016), many youths are not guided and they lack entrepreneurial skill that could be deployed to produce and market goods and services. The issue of unsatisfactory rating of personal-social counselling is not surprising. The finding is evident by the maladaptive behaviour exhibited by some students in the school system, such as anger, mood swing, phobia, anxiety, restlessness, excessive frustration, withdrawal etc. these are problems that could affect students healthy personality development. Iwuama and Maduka (2014) reported that personal social counselling is a major focus of counselling yet little attention is paid to it. The goal of personal-social counselling is to help students to be well adjusted in the schools.

The observed gaps in the role expectation and performance of counselling duties was noted by Kolo, Bawa and Adisa (2012), whose view aligns with the findings of this study and suggested that professional school counsellors should demonstrate practical skills, make themselves relevant and useful in their field. Also in the same vein, Nwamuo and Ugwegbulam encouraged counsellors to discharge their comprehensive guidance and counselling professional roles for the betterment of students and society.

\subsection{Constraints to School Counsellor's Role Performance}

The finding of research question three revealed that professional school counsellors are faced with many constraints which could deter the smooth implementation of guidance and counselling programmes in the school system. Seventy five percent of school counsellors sampled acknowledged that they have no conducive counselling office, no funding of counselling programmes in their schools and non-inclusion of counselling period on their school time-table. Majority of the counsellors also claimed that they have no counselling working tools such as counselling books, computers, bulletin boardss, video recording tapes amongst others. Sixty percent of the counsellors sampled also claimed that they were assigned non counselling duties, while $40 \%$ of the counsellors claimed they were not.

From the findings, there is evidence of concordance of opinion on the provision of conducive counselling office and counselling materials. The result shows that conducive counselling office and working materials are partially being provided in schools. This result affirms the findings from the studies carried out by "Author" (2010) and Ohovwore (2018), that counsellors' needs are not being met satisfactorily in schools. This is to say that there is still much to be done in terms of meeting counsellors' needs in the school system. The effectiveness of the school 
counsellor in the discharge of their core duties depends largely on school principals' provision of enabling environment and work tools for the school counsellors. The finding of this study in the area of assigning noncounselling duties to school counsellors, reveals that school counsellors are assigned non-counselling duties. This result is in consonance with the finding of Nwamuo and Ugwuegbulam (2011), that school principals preferred school counsellors to carry out non-counselling duties such as; teaching, collection of fees, registration of students and computation of continuous assessment. This report also aligns with the opinion of Abdulkadir (2015) that principals use their powerful position, to assign inappropriate task to school counsellors.

It is conceivable that since school counsellors are subordinated to school principals, they may be finding it difficult to object to assignments given to them by their principals. However, the performance of non-counselling duties in addition to core professional roles may be over burdening of the counsellors in the school system, which could lead to job dissatisfaction and poor performance.

\section{Conclusions}

Based on the data and results of this study, the researcher is able to conclude that professional school counsellors are aware of their cognate roles in the school system and satisfactorily perform individual and group counselling, educational and referral services. However, certain constraints such as lack of working materials and non-funding of guidance programmes, non-inclusion of counselling period on the school time-table amongst others hinder their effectiveness in the conduct of their functions.

\subsection{Recommendations}

Based on the findings of this study, the following recommendations were made.

1. Considering the ever ascending relevance of the school counsellor in the successful implementation of Nigeria's educational initiatives as captured by the National Policy on Education, much more collaborative support needs to be given by the school principals to enhance counsellors' prosecution of their functions and eliminate the constraints to effective implementation of guidance and counselling services as indicated by the school counsellors.

2. There should be regular workshop for training and retraining of school counsellors, to enable them upgrade their knowledge and improve their counselling competences.

3. Continuous research on the subject matter investigated is required to sustain focus and ameliorative constraints interventions to the counselling services in the school systems in Nigeria.

\section{References}

Abdulkadir, O.R. (2015). Organization and administration of guidance and counselling in school. Lagos: Nathadex publisher.

Anagbogu, M.A. (2002). Foundations of guidance and counselling for colleges and universities. Akwa. Ikenga publishing company.

Denga, D. I. (2019). Introduction to guidance and counselling. In Egbochuku, E.O \& Ifelunni, I.C.S. (Eds). Counselling and human development in Nigeria. Benin. Ambik press Ltd.

Egbo, J.O.E. (2013). Guidance and counselling, life skills education and human resource development; towards achieving the goals of the education for all (EFA) agenda. A paper delivered at the $8^{\text {th }}$ annual conference of the association of teachers at the NOUN study centre. Enugu. July 8-12.

Egbo, J.O.E. (2015). School guidance services as veritable intervention strategies for students with special needs. In Adegoke, A.A, Aluede, O, \& Eweniyi, G.(Eds). Issues in the helping profession for Nigerian counsellors. Counselling Association of Nigeria.

Egbochukwu, E.O. (2008). Guidance and counselling: A comprehensive text: Benin city. University of Benin press. Federal Republic of Nigeria (2013). National policy on education. Lagos: NERDC press.

Hammed, T.A.(2019). The image of the Nigerian counsellor. In Egbochuku, E.O \& Ifelunni, I.C.S. (Eds). Counselling and human development in Nigeria. Benin: Ambik press Ltd.

Idowu, A.I. (2004). Guidance and counselling: An overview. In A.I. Idowu (Ed). Guidance and counselling in education. Ilorin. Indemec publishers (Nig) Ltd.

Iwuama, B.C \& Maduka, N.J. (2014). Helping personality through counselling. In Adegoke, A.A. \& Aluede, O. (Eds). Perspectives in guidance and counselling. Benin city. Justice Jeco printing and publishing global.

Jiya, J. (2014). Counselling dimension of academic reconstruction in the quest for school effectiveness in Nigeria. In Adegoke, A.A. \& Aluede, O (Eds). Perspectives in guidance and counselling. Benin city. Justice Jeco printing and publishing global.

Kolo, F.D, Bawa, J.O \& Adisa, S (2012). Need for skills improvement among Nigerian Counsellors. The counsellor. 31(2) 14-23.

Nwamuo, P.A. \& Ugwegbulam, C.N. (2011). Challenges of effective implementation of comprehensive school guidance and counselling programme. The counsellor. 30(2). 73-84. 
Ohovwere, C.A. (2018). The problem militating against the implementation of guidance and counselling services in secondary school in Ndokwa East L.G.A. Delta State University. (Unpublished PGDE Project)

Ojeme, A.I. (2010). Critical incidents facilitating secondary school guidance counsellor principal relationship in Edo and Delta State. University of Benin: (Unpublished Ph.D thesis).

Okeke, B.A. (2003). Principles of guidance and counselling: An outline for beginners, Enugu. SNAAP press Ltd. Omebe, S.E. (2005). Guidance and counselling: A comprehensive approach. Enugu: Cheston Publishers.।

Robins, S.P. (2001). Organizational behaviour. (19 ${ }^{\text {th }}$ ed). New Delhi. Prentice hall.

Schmidt, J.J. (2014). Counselling in the schools: Essential services and comprehensive programs ( $\sigma^{\text {th }}$ ed). Boston. Allyn and Bacon.

Tambawal, A.B \& Abdulkarim, H.W. (2016). Entrepreneurship Education Counselling for Youths in Sokoto State: Implication for national security. In Adegoke, A.A, Aluede, O. \& Eweniyi, G (Eds). Critical Essays in Guidance and Counselling for Nigerian Counsellors. Counselling Association of Nigeria (CASSON).

Torbaba, E.O. (2009). Career development. Boston. Houghton Mifflin Company.

Unachukwu, G.C. \& Igborgbor, G.C. (2001). Guidance and Counselling. A realistic approach. Owerri. International Universities press.

Yakasai, M.I. (2019). Organization and administration of guidance and counselling services. In Egbochuku, E.O \& Ifelunni, I.C.S. (Eds). Counselling and human development in Nigeria. Benin: Ambik press Ltd.

Author: Dr (Mrs) Agatha Ojeme is a lone author of this study. She is an Associate Professor in the Institute of Education, University of Benin, Benin City. Born on the $26^{\text {th }}$ of May 1959 in Lagos, Nigeria. She is a member of Counselling Association of Nigeria since 2010 till date. She was the business editor of Benin Journal of Educational Studies (BJES) from 2011 to 2020. The author holds a PhD degree in Counselling Psychology from the University of Benin, Benin City, Edo State Nigeria in the year 2010. She specialized in School Base Counselling and Early Childhood Education. She has contributed immensely to the development of teacher education in Nigeria through teaching scholarly publications and counselling services. 